\title{
Role of Military Termites (Pseudocanthotermes militaris) in Improving Soil Productivity in Tropical Agroecosystems
}

\author{
Samuel Obeng Apori ${ }^{1,2,3^{*}}$, Murongo Marius Flarian ${ }^{1,4}$, Emmanuel Hanyabui $^{2}$, \\ Gideon Kalii Muli ${ }^{1,3}$ and Beatrice Wamuyu ${ }^{1,3}$ \\ ${ }^{1}$ African Center of Excellence in Agroecology and Livelihood Systems, Faculty of Agriculture, \\ Uganda Martyrs University, Uganda. \\ ${ }^{2}$ Department of Soil Science, University of Cape Coast, Ghana. \\ ${ }^{3}$ Faculty of Agriculture, Uganda Martyrs University, Uganda. \\ ${ }^{4}$ Ecological Organic Agriculture Initiative, Uganda.
}

\begin{abstract}
Authors' contributions
This work was carried out in collaboration among all authors. All the authors made corrections, read and approved for final publication.

Article Information

DOI: 10.9734/ARRB/2020/v35i530221

Editor(s):

(1) Dr. Lucas Petigrosso, FCA-UNMdP, Argentina. Reviewers:

(1) Chemutai Roseline, Bukalasa Agricultural College, Uganda. (2) Rogerio Silvestre, Universidade Federal da Grande Dourados- UFGD, Brazil. Complete Peer review History: http://www.sdiarticle4.com/review-history/55867
\end{abstract}

Review Article

Received 10 February 2020

Accepted 14 April 2020

Published 18 June 2020

\section{ABSTRACT}

Military Termites have been considered as a major pest causing significant reduction to crop productivity in tropical regions of the world. The termite destroys many plants (domestic and wild) at any stage of development from the seedlings to maturity. Crops such as cotton, wheat and ground nuts, upper land rice and eucalyptus trees are highly susceptible to termite damage. They destroy huge amounts of organic materials especially those used as mulches in plantation farming. However, there are beneficial termite activities such as organic matter decomposition and nutrient dynamics that are essential components in the soil ecosystem as they aid in maintaining long-term soil productivity and also in restoring barren soils. The review sought to establish the contribution of military termite activities to soil productivity. The result from the review showed that termite activities such as burrowing, chewing of plant litter, excavation activities in search of food, and construction of termitaria leads to improved soil structure, soil aeration, water infiltration via soil 
porosity, plant nutrient (calcium, nitrogen, phosphorus, potassium, magnesium) and soil organic matter which will eventually result to improved yields of crops. Also, termite mound has been suggested to be very effective for bulking agent for compost preparation and soil amendment.

Keywords: Termite; mound; chemical; physical and biological.

\section{INTRODUCTION}

Termites are insects classified at the taxonomic rank of infrared Isoptera. They are soil animals since they spend some part of their life cycle in the soil; together with their association with the soil, they have several effects on soil properties [1]. Termites are among the macrofauna that influence soil physical, chemical and biological properties. They are more active in the semi-arid and arid areas (this is missing in the general topic) [2]. According to [3], termites account for 40 to $60 \%$ of the total soil macrofauna biomass in many tropical ecosystems. Their estimated biomass in African savannas is estimated to be between 70 to $110 \mathrm{~kg} / \mathrm{ha}$ [3]. Several studies have shown that termites are able mechanically to chew up plant material with their mandibles and grind it with their gizzard, thereby increasing the surface area accessible to soil microorganisms. However, some termite species are essential in maintaining long-term soil productivity and also in restoring barren soils [4]. Termite accumulate and deposit particles from various soil depths in mounds so that the amount of organic carbon, clay and nutrients, $\mathrm{pH}$ and microbial communities is higher in termite mounds than in adjacent termite-free soils [5]. Termites contribute to the regeneration of crusted soils by creating voids on the sealed surface, resulting in increased potential for infiltration, and ultimately enhanced water quality [6]. Hence this review seeks to find out the contribution of termites through their physical, chemical and biological influence on soil and how it enhances soil productivity.

\section{COMMON TERMITES' FAMILIES IN THE TROPICS}

\begin{tabular}{lll}
\hline Family & Habitat & Source \\
\hline Mastotermitidae & Dry forest/savanna & {$[7]$} \\
Hodotermitidae & Arid grasslands & {$[8]$} \\
Kalotermitidae & Tropical forest canopies, oceanic islands, coasts & {$[9]$} \\
Serritermitidae & Tropical forests & {$[10]$} \\
Rhinotermitidae & Forest edges (and centers) & {$[11]$} \\
Macrotermitinae & Forests and savannas & {$[12]$} \\
Apicotermitinae & Tropical forests and savannas & {$[13]$} \\
Termitinae & Tropical forest (all tropical areas) & {$[14]$} \\
Nasutitermitinae & Tropical forest (all tropical areas) & {$[15]$} \\
\hline
\end{tabular}

\section{FUNCTIONAL ACTIVITY OF TERMITES VERSUS TERMITE MOUND MICROORGANISMS}

Termites feed on plant materials by transportation (Live and dead plants, litter in various stages of decay in dung, soil and specialized food such as lichens in their mound. The chewing of the plant materials aid in rapid decomposition hence contributing to the organic matter in the soil [16]. The importance of nonmutualistic microorganisms in termite mounds is determined by the variety of organisms' present. The combination of mountain microorganisms and termites was thought to have a positive impact on the decomposition of organic matter and nutrient cycling, particularly in more arid ecosystems [17]. The microbial biomass present in mound soil exceeds that of the termite population and that the ratio of microbial biomass carbon to termite biomass carbon was approximately 20:31 in an average mound, suggesting a relatively large microbial community [16]. Cellulose decomposers are a predominant group of bacteria found in termite mound soil, suggesting that cellulosic material degrades more quickly in mound soil than in surface soil unaffected by termites [18]. As early as the 1960 s, it was established that large numbers of nitrifying and denitrifying bacteria are found in termite mound soils [19]. The presence and activity of these organisms have also been determined indirectly by assaying end products of both the nitrifying and denitrifying process 
(nitrate and nitrous oxide respectively) [17] Nitrate rates exceeding 100 ppm were measured in the mounds of some termites, and significant $\mathrm{N}_{2} \mathrm{O}$ fluxes from termite mounds were also reported [20]. In certain areas of some termite mounds, there are also some records of low microbial activity and the possibility that termite excretions may have bacteriostatic properties [16].

\section{INFLUENCE OF TERMITES ON SOIL PHYSICAL PROPERTIES}

Termites play a major role in the ecosystem which deals with soil loosening (reduction of bulk density) and both vertical and horizontal transport through bioturbation and subsequent erosions of their constructions. Large amounts of soil are translocated from various depths of the profile to the soil surface during mound-, galleryand sheeting constructions [12]. Considering rare earth element $(\mathrm{Ni}, \mathrm{Cu}$, and $\mathrm{Zn})$ and the concentration of trace element, the nests of Macrotermes $s p$. are produced through the accumulation of highly weathered soil originating from deeper layers [21]. Termite has the potential for reduction of soil bulk density and influences the translocation of soil either vertical and horizontal transport by bioturbation and erosion of their mound hence, this magnitude and route of soil translocation resulting from termite activity is directly related to their dietary habits (litter feeding and wood chewing) and the properties of the soil they use. Generally, soil transported by termites contains higher proportions of finer particles size and therefore typically demonstrates different clay mineral compositions than those predominating at the original surface $[12,20]$.

Effect of termite activities on soil physical properties ranges from micromorphological to soil profile structure and evolution [1]. Termites are known to be a major contributor to soil turnover and the amount of biomass produced. Termites influence the alteration of the soil profile through; soil turnover and physical disturbance, decomposition of litter and biomass and creating deep galleries and burrows [22]. Termites affect the soil through their activities search as; burrowing and excavation activities in search of food, or the construction of living spaces or storage chambers in the soil or above-ground [23]. The burrows in the soil increase soil porosity resulting in high infiltration of the soil and bulk density. [24], performed experiments on the use of mounds of the termite Macrotermes falciger (gerstacker) as a soil amendment. The results obtained shows that termite mound had the lowest bulk density as compared to the surrounding soil. Moreover, termites increase water infiltration via porosity and soil structure improvement [25]. Termite increase water infiltration via porosity through creating tunnels. These tunnels find in the soil improved soil aeration, soil water availability through the macropores and soil turnover [4]. [22], found out that the termite restored the infiltration capacity of crusted soil through increased porosity, soil water content and less bulk density. Termite also increase soil aggregation by the secretion of substances that aid in biding of the soil particles Also, termite tunnels in the soil allow rainwater to percolate deep hence, reduce run-off and consequent soil erosion, through bioturbation [3].

\section{INFLUENCE OF TERMITES ON SOIL CHEMICAL PROPERTIES}

Termites alter the chemical properties of the soil by collection and transportation of living and dead, plant and animal materials, in and out of the termitaria. The effects of termite activities depend on soil properties termites' feeding behavior and materials utilized in nest building, termite species, vegetation and land use [2]. Termites accumulate organic matter in their hills. This leads to the increase of plant macronutrient such as nitrogen, phosphorus and potassium in the soil as compared to the adjacent soil. According to [25], the capacity of termites to increase nutrient levels such as nitrogen, phosphorus potassium, calcium and magnesium are dependent on the rate of organic material incorporation and the type of termitaria made by the termites. Termites generally modify the availability of nutrients either directly or indirectly for other organisms in the soil [3]. In an experiment performed by [24], termite mounds were combined with soil. The result showed high percentages of plant nutrient such as Calcium $95 \%$, mineral Nitrogen $81 \%$, extractable Potassium $69 \%$ and available Phosphorus $69 \%$. The activities of termite to improve soil nutrient aid in increasing the crops' biomass and grain yield. According to [26], the proximity of vegetation's growth and species structure to termites' mounds in semi-arid savannah ecosystem showed that the mounds influence nutrient and water availability, drainage of the soil, which in turn contribute to increased biomass. Besides, termites have been considered as weathering agents due to their ability to transform minerals chemically [21] it can 
be hypothesized that the grinding of soil particles by termite mandibles in the saliva-rich environment of the buccal cavity increases the surface area exposed to the surrounding solution and then releases interlayer $\mathrm{K}$ and adsorption of hydrated or polar ions between the layers [12].

\section{INFLUENCE OF TERMITES ON SOIL BIOLOGICAL PROPERTIES}

The termitarium is similar to the soil from which it is made because it normally includes large numbers of micro-organisms. These microorganisms, mainly fungi and bacteria, have different functions within the process of decomposition of organic matter [17]. The termite-fungal relationship can be divided into two groups, non-mutualistic and mutualistic. There are usually non-mutualistic interactions between dry wood termites and certain woodrotting pillows, with evidence suggesting that wood previously attacked by pillows is more favourable to these termites $[26,27]$. According to [17] mutualistic relationships between termites and fungi are restricted to termites in the Macrotermitinae and the fungus Termitomyces and have been particularly well studied. They further stated that the primary role of this fungus appears to be colony nutrition, which forms an extensive sporulating mycelium on aggregated, partially digested faecal pellets (forming characteristic structures within the mounds known as combs), the fungus has been attributed to other more specific functions. These include the provision of synergistic cellulolytic enzymes to facilitate digestion, decomposition of lignin and the provision of a nitrogen-enriched substrate for termites' ingestion [17]. Certain studies of termite mound soil microbiology have indicated the existence of large numbers of free-living bacteria and fungi not directly related to termite feeding. The found out that bacteria and fungi were more numerous in soil made from mound than in adjacent surface soils [18]. According to [12], several studies suggest that termites and sheets could be microbial diversity sites with a different assembly structure from the parent soil. They stated that increasing evidence suggests that termites are capable of controlling the numbers of microorganisms and probably diversity in selected parts of their mounds, such that the higher abundance of substrates, the nutrient content and the amounts of moisture available promote the growth of a selected and possibly specialized population of commensal bacteria and fungi.in selected parts of their mounds.

\section{PRACTICAL APPLICATION OF TERMITES IN AGROECOLOGY}

Termite activity is of great importance while mulching in crusted soils. The organic matter used for mulching purposes is broken down by the termite especially during the dry periods hence increasing water infiltration [23]. Termite mounds have also been suggested to be effective bulking agents for compost preparation. Fungus growing termites (Macroterminitae, Isoptera) are associated with termitomyces mushrooms [28]. Fungus growing termites cultivate fungal crops in farms within their colonies. They are found through-out old world tropics in savannas and rain forests. Fungus growing by termites is ecologically most successful under the unfavourable conditions of the savanna but that seems to have changed under more constant and favourable conditions of the rainforest [29]. There is a symbiotic relationship between the fungus-growing termites (Macroterminitae, Isoptera) and the termitomyces mushrooms whereby the fungus mushroom produces the faecal pallet which come together and form a spongy-like structure called fungus comb. The mushrooms grow on the fungus comb [30]. Fungus growing termites cultivate symbiotic fungi in the nest and feed on the fungus garden/ comb.

\section{NEW RESEARCH VIEWPOINTS}

Termite mound has been found to be very effective for soil amendment [31] however, its combination with other organic resources such as biochar, compost, manure on soil quality indicators and crop productivity are areas providing opportunities for further study. Phytotoxicity and compost quality assesment produced from available waste product has been well documented but there is limited information available on compost quality and composting studies during composting of waste materials blended with termite mound.

\section{CONCLUSION AND RECOMMENDA- TIONS}

Termites are among the macrofauna that influence soil physical, chemical and biological properties through their functional activities. Termite activities aid in the improvement of soil porosity, organic matter through decomposition, water infiltration, availability of soil water, soil aggregation, nitrogen, potassium, calcium, magnesium and phosphorus availability. 
Composting of crop residues with termite mound and soil amendment has shown to be promising one to improve soil fertility. It is, therefore, necessary for farmers to conserve these mounds on their fields and utilize it beneficial use.

\section{ACKNOWLEDGEMENTS}

The authors thank Ecological Organic Agriculture initiative for their financial support and encouragement.

\section{COMPETING INTERESTS}

Authors have declared that no competing interests exist.

\section{REFERENCES}

1. Holt JA, Lepage M. Termites and soil properties. In: Abe, T., Bignell, D.E., Higashi, M. (Eds.), Termites: Evolution, Sociality, Symbioses, Ecology. Springer Netherlands, Dordrecht. 2000;389-407.

2. Lal R. Effects of macrofauna on soil properties in tropical ecosystems. Agriculture, Ecosystems \& Environment. 1998;24:101-116.

3. Moe SR, Mobæk R, Narmo AK. Mound building termites contribute to savanna vegetation heterogeneity. Plant Ecol. 2009;202:31-40.

4. Kaiser D, Lepage M, Konaté S, Linsenmair KE. Ecosystem services of termites (Blattoidea: Termitoidae) in the traditional soil restoration and cropping system Zaï in Northern Burkina Faso (West Africa). Agriculture, Ecosystems \& Environment. 2017;236:198-211.

5. Deke LA, Adugna TW, Fite TA. Soil physicchemical properties in termite mounds and adjacent control soil in Miyo and Yabello Districts of Borana Zone, Southern Ethiopia. American Journal of Agriculture and Forestry. 2016;4(4):69-74.

6. Calovi DS, Bardunias P, Carey N, Scott Turner J, Nagpal R, Werfel J. Surface curvature guides early construction activity in mound-building termites. Philos. Trans. R. Soc. B. 2019;374:20180374.

7. Wappler T, Engel MS. A new record of mastotermes from the eocene of germany (isoptera: mastotermitidae). Journal of Paleontology. 2006;80:380-385.

8. Picker MD, Hoffman MT, Leverton B. Density of Microhodotermes viator (Hodotermitidae) mounds in Southern Africa in relation to rainfall and vegetative productivity gradients. J Zoology. 2007;271:37-44.

9. Desai MS, Strassert JFH, Meuser K, Hertel $\mathrm{H}$, Ikeda-Ohtsubo W, Radek R, Brune A. Strict cospeciation of devescovinid flagellates and Bacteroidales ectosymbionts in the gut of dry-wood termites (Kalotermitidae). Environmental Microbiology; 2009.

10. Bourguignon $T$, Šobotník J, Hanus $R$, Roisin Y. Developmental pathways of Glossotermes oculatus (Isoptera, Serritermitidae): At the cross-roads of worker caste evolution in termites. Evolution \& Development. 2009;11:659668.

11. Lo N, Kitade O, Miura T, Constantino R, Matsumoto T. Molecular phylogeny of the Rhinotermitidae. Insect. Soc. 2004;51:365-371.

12. Jouquet $P$, Tessier $D$, Lepage $M$. The soil structural stability of termite nests: Role of clays in Macrotermes bellicosus (Isoptera, Macrotermitinae) mound soils. European Journal of Soil Biology. 2004;40:23-29.

13. Costa-Leonardo AM. A new interpretation of the defense glands of neotropical ruptitermes (Isoptera, Termitidae, Apicotermitinae). 2004;44:13.

14. Bignell DE, Oskarsson $\mathrm{H}$, Anderson JM. Association of actinomycete-like bacteria with soil-feeding termites (Termitidae, Termitinae). Applied and Environmental Microbiology. 1979;37:339-342.

15. Prestwich GD, Jones RW, Collins MS. Terpene biosynthesis by nasute termite soldiers (Isoptera: Nasutitermitinae). Insect Biochemistry. 1981;11:331-336.

16. Enagbonma BJ, Aremu BR, Babalola OO. Profiling the functional diversity of termite mound soil bacteria as revealed by shotgun sequencing. Genes. 2019;10:637.

17. Abe $T$, Bignell DE, Higashi M, (Eds.). Termites: Evolution, sociality, symbioses, ecology; 2000.

18. Enagbonma BJ, Babalola OO. Environmental sustainability: A review of termite mound soil material and its bacteria. Sustainability. 2019;11(14):3847.

19. Meiklejohn J. Microbiological studies on large termite mounds. Rhod. Zamb. Mal. J. Agric. Res. 1965;3:67-79.

20. Abe SS, Wakatsuki T. Possible influence of termites (Macrotermes bellicosus) on forms and composition of free sesquioxides in tropical soils. Pedobiologia. 2010;53:301-306. 
21. Sako A, Mills AJ, Roychoudhury AN. Rare earth and trace element geochemistry of termite mounds in Central and Northeastern Namibia: Mechanisms for micro-nutrient accumulation. Geoderma. 2009;153:217-230.

22. Mando A, Stroosnijder L, Brussaar L. Effects of termites on infiltration into crusted soil. Geoderma. 1996;74:107-113.

23. Mando A. The impact of termites and mulch on the water balance of crusted Sahelian soil. Soil Technology. 1997;11:121-138.

24. Watson JP. The use of mounds of the termite Macrotermes falciger (Gerstäcker) as a soil amendment. Journal of Soil Science. 1977;28:664-672.

25. de Bruyn L, Conacher A. The role of termites and ants in soil modification - a review. Soil Res. 1990;28:55.

26. Arshad MA. Influence of the termite Macrotermes michaelseni (Sjöst) on soil fertility and vegetation in a semi-arid savannah ecosystem. Agro-Ecosystems. 1982;8:47-58.

27. Wappler T, Engel MS. A new record of mastotermes from the eocene of germany (isoptera: mastotermitidae). Journal of Paleontology. 2006;80:380-385.

28. Hsieh HM, Chung MC, Chen PY, Hsu FM, Liao WW, Sung AN, Lin CR, Wang CJR, Kao YH, Fang MJ, Lai CY, Huang CC, Chou JC, Chou WN, Chang BCH, Ju YM. A termite symbiotic mushroom maximizing sexual activity at growing tips of vegetative hyphae. Bot Stud. 2017;58:39.

29. Brossard M, López-Hernández D, Lepage M, Leprun JC. Nutrient storage in soils and nests of mound-building Trinervitermes termites in Central Burkina Faso: Consequences for soil fertility. Biol. Fertil. Soils. 2007;43:437-447.

30. Ohkuma M, Maeda Y, Johjima T, Kudo T. Lignin degradation and roles of white rot fungi: Study on an efficient symbiotic system in fungus-growing termites and its application to bioremediation. Riken Rev. 2001;42:39-42.

31. Garba M, Cornelis WM, Steppe K. Effect of termite mound material on the physical properties of sandy soil and on the growth characteristics of tomato (Solanum lycopersicum L.) in semi-arid Niger. Plant Soil. 2011;338:451-466.

(c) 2020 Apori et al.; This is an Open Access article distributed under the terms of the Creative Commons Attribution License (http://creativecommons.org/licenses/by/4.0), which permits unrestricted use, distribution, and reproduction in any medium, provided the original work is properly cited.

Peer-review history:

The peer review history for this paper can be accessed here: http://www.sdiarticle4.com/review-history/55867 